\title{
The Influence of Macroeconomics Variables on Foreign Direct Investment (Empirical Study from Indonesia)
}

\author{
Bagus Nurcahyo \\ Management Department \\ Gunadarma University, Jakarta, Indonesia \\ Renny Nur'ainy \\ Accounting Department \\ Gunadarma University, Jakarta, Indonesia \\ Sri Nawangsari \\ Management Department \\ Gunadarma University, Jakarta, Indonesia
}

\begin{abstract}
This paper studies the mutual effects of foreign exchange rate, economic growth and inflation using a case study of Indonesia. By analyzing them we founded that Foreign Exchange Rate, Economic Growth, and Inflation simultanously influence to the FDI in Indonesia. Foreign Exchange Rate and Economic Growth have positive influence to FDI in Indonesia but Inflation has no impact on FDI in Indonesia. It means that FDI in Indonesia depends on Foreign Exchange Rate, Economic Growth.
\end{abstract}

Key Words: Foreign Exchange Rate, Economic Growth, Inflation, FDI, Indonesia

\section{RESEARCH BACKGROUND}

According to the raising of global economic growth, increasing the linkage needs across country were increased the flow of trade in goods, money and capital between developing country. This condition was push by the increasing of market capitalizing, higher economic growth, and high interest rate (especially in developing country). The raising ini capitalizing capital mobilization across country is a vehicle to investor risk diversification. This is done in order to face the uncertainty of the existence of economic turmoil, social, cultural, and politics in several country, Hal ini dilakukan sebagai upaya menghadapi ketidak pastian dari adanya gejolak ekonomi, sosial, budaya dan politik di berbagai negara, so that investors can avoid or minimize the risk of investing their funds in (Indonesian Central Bank, 2003).

In Indonesia, Foreign direct investment (FDI) introduced in 1967, when the Indonesian government issued The Law of Foreign Investment No.1/1967. In the early period of economic development around the middle of 1960 to early 1970, Indonesia needs foreign loans and foreign investment to make the most of the abundant natural resources owned so as to accelerate economic growth. If foreign aid is needed to finance government spending in developing economic growth, foreign investment function itself is expected to accelerate growth in the industrial sector.

This study investigated the influence of foreign exchange rates, economic growth and inflation on foreign direct investment in Indonesia. According to this we will examine how the foreign 
exchange rates, economic growth and inflation influencing on foreign direct investment or FDI in Indonesia.

\section{Foreign Exchange Rate}

\section{LITERATURE REVIEW}

Exchange rate defined as the domestic currency price in units of foreign currency rates (Salvatore, 1997). The price or value of the illustrates some of the many a currency must be exchanged to obtain one unit of another currency.

Exchange rate has a central role in international trade relations, because the exchange rate allows us to compare the prices of all goods and services produced by various countries, especially in the export and import transactions. The exchange rate has a negative effect on a country's exports (Sudarmadi, 2013).

In a sense, that the decline in the exchange rate (the domestic currency value fall against foreign currencies) will increase exports, because if a country's domestic currency fell against the currencies of other countries, the economic actors who do export to other countries will get benefit greater than the difference in the decline rate of the domestic currency against the currencies of other countries (short-term gains) (Sudarmadi, 2013).

Exchange rate is the primary variable affecting domestic and foreign relations. Exchange rate reflects the basic economic factors that can act as a very strong helper element in allocating resources in line with the comparative advantage of a country (Warren, 1988). Changes in currency exchange rates will make investors difficult to predict the value of a project and will not assist in the analysis of investment plans (Benassy Quéré, 2001).

\section{Economic Growth}

There are two schools thought on the growth of economies when viewed from the production that is in accordance with the theory of neo classical and modern theory. According to the theory of neo classical, production factors are considered to be very influential on the growth of output are the sum of labor and capital. Meanwhile, according to the modern theory, the factors of production are considered equally important, not only labor and capital, but also changes in technology, raw materials and materials itself. In addition other factors that influence economic growth is the availability and condition of infrastructure, laws, and regulations, political stability and so forth (Tambunan, 2001).

Economic growth is the addition of the Gross Domestic Product (GDP), which means the addition of National Revenue (PN). Economic growth is a process of increasing the production capacity of the economy as a comprehensive, continuous and sustainable than increase national income greater (Todaro, 2000). Economic growth according to Suparmoko (1998) is one of the important objectives of macroeconomic policy related physical size by increasing the production of goods and services. Based on these description, economic growth has three important aspects, growth as a process, related to the level of national income, and long-term perspective.

\section{Inflation}

According to Khalwaty (2000), inflation is a condition that indicates the increasingly weakening purchasing power steadily decline followed by a real value (intrinsic) of a country's currency. Briefly inflation can be interpreted within a state in which there is an increase in prices that made the nation's currency value falls proportional to the increase in prices of these goods. The increasing of price is not solely due to the influence of the properties of goods, technology, and the scarcity of seasonal goods, but because of the effect of inflation, which 
generally takes place in a long time (Sudarmadi, 2013).

Inflation can be divide two categories such as domestic inflation and imported inflation. Domestic inflation is inflation comes from domestically. The increase in prices is a result of shock or shocks from domestic, both people's behavior and the behavior of government in issuing policies that could lead to psychological inflation. The price increase that occurred in absolute terms and will lead to inflation or increase the rate or the rate of inflation (Sudarmadi, 2013).

\section{Foreign Direct Investment}

Definition of investment are expenses that are intended to improve or maintain the stock of capital goods (capital stock) is composed of a factory, office machinery, and others durable product (Dornbusch \& Fischer, 1994). Meanwhile, according Khalwaty (2000), investment is an investment of capital for one or more assets owned and usually long term to benefit in the future.

According to Robin Bade and Michael Parkin (2002), investment is the purchase (production) of goods which are not consumed but used for future production such as tools, equipment, machinery, and buildings. Meanwhile, Gwartney (2006), said investment is the purchase, construction and development of resources including natural and human resources.

Ball \& McCulloch (2000) foreign investment can be divide in two components. The first component is the investment portfolio, which is the purchase of stocks and bonds solely with the purpose of obtaining a return on funds invested. The second component is a direct investment, where investors participate in the management of the company in addition to receiving a return on their money. They said, the notion of portfolio investment is the purchase of stocks and bonds to earn a return on the funds invested. While the foreign direct investment (FDI) briefly by Ball \& Mulloch (2000) is purchasing enough shares in a company to obtain significant management control.

Definition of FDI according to Act 1 of 1967 on foreign investment is foreign direct investment undertaken by or under the provisions of law in Indonesia, in the sense that the owners of capital are directly bear the risk of such investments. Suharto (1997), also found an explanation of the definition of FDI, where FDI is an international movement of capital which has the characteristics of the various factors of production include management, technology and marketing expertise that accompanies displacement field of the capital. While the portfolio investment is an international capital movement is caused by the increasing attractiveness of profit (return) in marketable securities, and reduce risk.

Further Suharto (1997) also revealed differences between the portfolio investment and foreign direct investment, which is more emphasis on the managerial control of the company concerned in managing displacement. So, if the investor directly to supervise their direct foreign investment (foreign enterprise) is called with FDI and if it does not have direct oversight called portfolio investment.

Many and great variety of opinions on the definition of the two components of overseas investment described by economists in the world, can be summarized and concluded in the following table: 
TABLE 1 THE DIFFERENCE BETWEEN FDI AND PORTFOLIO

\begin{tabular}{|l|l|l|}
\hline \multicolumn{1}{|c|}{ Form } & \multicolumn{1}{|c|}{ FDI } & \multicolumn{2}{c|}{ Portfolio } \\
\hline Type of Investor & Corporate & $\begin{array}{l}\text { Individual } \\
\text { market and capital }\end{array}$ \\
\hline Capital Objective & Manufacturing & $\begin{array}{l}\text { Security profit and } \\
\text { interest rate }\end{array}$ \\
\hline Motivation & $\begin{array}{l}\text { Profit and Corpporate } \\
\text { growth }\end{array}$ & None \\
\hline $\begin{array}{l}\text { Direct Supervision of the } \\
\text { corporate }\end{array}$ & Exist &
\end{tabular}

Source: Suharto (1997); Sudarmadi (2013)

\section{Previous Study on FDI in Indonesia}

Sarwedi (2002) conducted a study on the factors affecting foreign direct investment in Indonesia during the period 1978 to 2001. Results of tests performed conclusion is; First, in the short term it was found that the variables of GDP, economic growth, wages and exports showed a positive and significant influence to explain the factors affecting foreign direct investment in Indonesia. Second, while in the long run, all independent variables showed a negative relationship. This is caused by fluctuations in the value of each of the variables that drive a change in the long-term equilibrium. Third, the political stability variable measured by the indicators figures riots or strikes that occurred in Indonesia during the study period was negative and significant in both the short and long term.

With the same objective but using different variables, Sambodo (2003) test the influence of gross domestic product, real deposit interest rate, foreign interest rate, exchange rate and position of public funds in banks on foreign direct investment (FDI) in Indonesia during the pre-crisis period (1993-1997) and the current crisis (1997-2001). Data were analyzed using linear model (error correction method). The results showed that in the short-term and longterm foreign investment in Indonesia before the economic crisis occurred significantly influenced by the exchange rate, the position of public funds, and interest rates. When the economic crisis, FDI is significantly affected in the short term and long term by the gross domestic product and interest rates, while the position of public funds in the bank just in the short-term effect on FDI in Indonesia.

Research on factors affecting investment has also been made by Salim Isa (2006) in the agricultural sector. However, do not distinguish capital from domestic and foreign (FDI). Variables were tested as factors affecting investment in the agricultural sector in Indonesia is growth in gross domestic production (GDP), foreign exchange rate, the price index of agricultural products, interest rates and inflation with the observation period from 1984 2004. The results showed that the growth of gross domestic product (GDP), foreign exchange rate, the price index of agricultural products, interest rates and inflation simultaneously affect the amount of investment in the agricultural sector.

In contrast to previous research in Indonesia, involving variables of FDI inflows into China. Kurniati, Prasmuko and Yanfitri (2007) examines the effect of economic growth, infrastructure and political stability as well as the impact of FDI inflows into China on FDI inflows into Indonesia. By using multiple linear regression to examine the effect of economic growth, infrastructure and political stability, while to examine the impact of FDI inflows into China gravity analysis.

The results were obtained several conclusions that can prove the above factors have an influence on FDI. Significantly economic growth, infrastructure and political stability has a positive impact on FDI flows to Indonesia. While using gravity analysis, researchers found 
impact of FDI flows to China. China's FDI growth had a positive effect on Indonesia's FDI, because Indonesia is a networking production (raw materials importing country) to China.

Recent studies, in 2012 Hussain and Kumili conducted a study of several factors that affect a country's FDI inflows. The study aimed to determine the effect of the gross domestic product, inflation and the import tariff on foreign direct investment (FDI) in developing countries. Tests carried out using Ordinary Least Square (OLS). From the results of tests performed it is concluded that FDI inflows to developing countries in the period 2000 to 2009 was significantly influenced by the gross domestic product, import tariffs and inflation. The positive influence derived from gross domestic product, while the negative effect derived from import tariffs and inflation.

\section{METHODOLOGY}

The purpose of this study is to test the influence of foreign exchange rate, economic growth and inflation on foreign direct investment (FDI) in Indonesia from 2002 to 2012. In this study, to obtain an accurate assessment we used Ordinary Least Square (OLS) to see how the FDI influenced by those variables. Consideration using OLS method because this method has the properties that can be seeded, which is technically very strong, easy withdrawal in the calculation and interpretation. Besides that, also because of the nature of the OLS estimator is no bias in the estimator has the minimum variance (Gujarati, 2003).

Period used in this study was between 2002 to 2012. During the intervening time Indonesia in the early period of emerging country from the economic crisis in 1998 and the global crisis in late 2008.

The variables used in this study are: dependent variable, is the FDI inflows to Indonesia, which is denoted by the FDI and independent variables, are foreign exchange rate which is denoted by $\mathrm{R}$, which is denoted by economic growth denoted by GRWT and inflation in Indonesia denoted by INF.

To operate these variable in this research we used FDI as the amount of FDI inflows inti Indonesia that measured by USD (\$) during period 2002 to 2012. Foreign exchange rate is the amount of IDR that can be change into USD, we used foreign exchange rate during period 2002 -2012. Economic Growth used during period 2002 -2012, measured by GDP on constan price to see real growth year to year. Inflation we used the inflation in Indonesia dusring period 2002 2012.

To find or solve the problems that will be examined used multiple linear regression model that has been developed into the following equation:

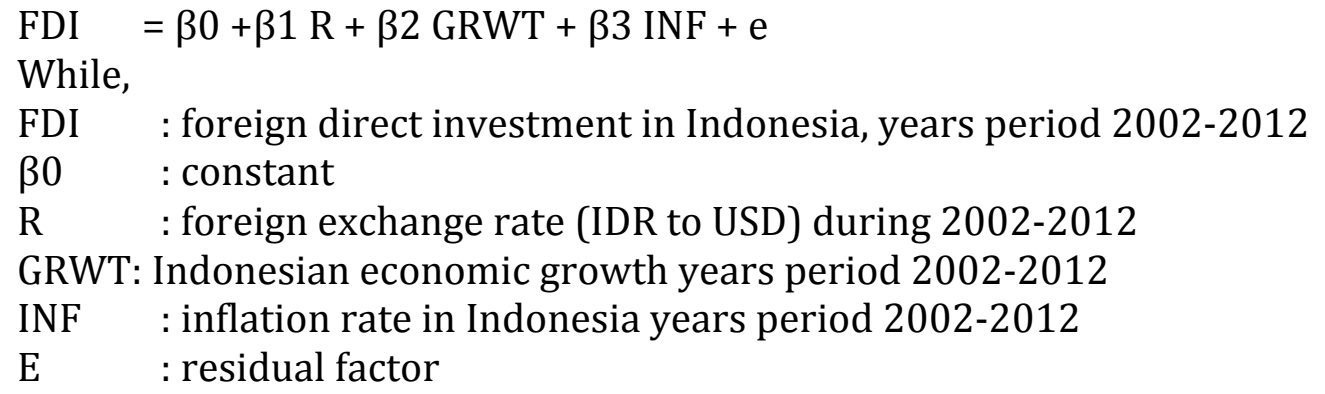

We used adjusted R2 to measure how well the dependent variable predicted by independent variables, $\mathrm{t}$ test used to detect how well the independent variables affected the dependent 
variable individually, and $\mathrm{F}$ test used to examine the independent variables affected the dependent variable simultaneously.

\section{Foreign Exchange Rate}

\section{DESCRIPTIVE STATISTIC}

At the midterm of 2001 (July 2001) the transfer of the national leadership, has impact on increasing market trust triggered by expected for ending of political crisis. To see the change in foreign exchange rate let us see table 2

TABLE 2 FOREIGN EXCHANGE RATE IN INDONESIA 2002-2012

\begin{tabular}{|c|r|}
\hline YEARS & \multicolumn{1}{|c|}{ R } \\
\hline 2002 & 9.253 \\
\hline 2003 & 8.566 \\
\hline 2004 & 8.985 \\
\hline 2005 & 9.751 \\
\hline 2006 & 9.141 \\
\hline 2007 & 9.164 \\
\hline 2008 & 9.929 \\
\hline 2009 & 10.356 \\
\hline 2010 & 9.154 \\
\hline 2011 & 8.773 \\
\hline 2012 & 9.419 \\
\hline
\end{tabular}

Source: SEKI, Central Bank of Indonesia

\section{Economic Growth}

Indonesian economic growth during the observation period 2002-2012 is growing positively as seen on table 3 below:

TABLE 3 ECONOMIC GROWTH IN INDONESIA 2002-2012

\begin{tabular}{|c|r|}
\hline YEARS & \multicolumn{1}{|c|}{ GRWT } \\
\hline 2002 & 3,66 \\
\hline 2003 & 4,10 \\
\hline 2004 & 5,13 \\
\hline 2005 & 5,60 \\
\hline 2006 & 5,50 \\
\hline 2007 & 6,30 \\
\hline 2008 & 6,10 \\
\hline 2009 & 4,50 \\
\hline 2010 & 6,10 \\
\hline 2011 & 6,50 \\
\hline 2012 & 6,23 \\
\hline
\end{tabular}

\section{Inflation}

As seen on table 4 we know that inflation rate in Indonesia moving average on low to medium, years to years always changes. 
TABLE 4 INFLATION RATE IN INDONESIA 2002-2012

\begin{tabular}{|c|r|}
\hline YEARS & \multicolumn{1}{|c|}{ INF } \\
\hline 2002 & 10,00 \\
\hline 2003 & 5,10 \\
\hline 2004 & 6,06 \\
\hline 2005 & 17,10 \\
\hline 2006 & 6,60 \\
\hline 2007 & 6,60 \\
\hline 2008 & 11,10 \\
\hline 2009 & 2,80 \\
\hline 2010 & 5,30 \\
\hline 2011 & 5,10 \\
\hline 2012 & 4,28 \\
\hline
\end{tabular}

Source: SEKI, Central Bank of Indonesia

\section{FDI}

As we know that FDI inflow to Indonesia during 2002 -2012 was not stable. In 2002, FDI inflow was US\$ 3.090,20 milion, it was the lowest during the observation periods (2002-2012). This condition was influenced by the political stability. To see the change on FDI inflow in Indonesia during 2002-2012, see the table 5 below:

TABLE 5 FDI INFLOWS IN INDONESIA 2002-2012

\begin{tabular}{|c|r|r|}
\hline YEARS & \multicolumn{1}{|c|}{$\begin{array}{c}\text { FDI } \\
\text { (milions } \\
\text { US\$) }\end{array}$} & $\begin{array}{c}\text { FDI monthly } \\
\text { in average }\end{array}$ \\
\hline 2002 & $3.090,20$ & 257,52 \\
\hline 2003 & $5.450,60$ & 454,22 \\
\hline 2004 & $4.601,30$ & 383,44 \\
\hline 2005 & $8.914,60$ & 742,88 \\
\hline 2006 & $5.976,90$ & 498,08 \\
\hline 2007 & $10.341,40$ & 861,79 \\
\hline 2008 & $14.571,40$ & $1.214,30$ \\
\hline 2009 & $10.815,30$ & 901,27 \\
\hline 2010 & $12.737,00$ & $1.061,42$ \\
\hline 2011 & $19.642,00$ & $1.636,83$ \\
\hline 2012 & $19.853,00$ & $1.654,42$ \\
\hline
\end{tabular}

Source: SEKI, BKPM

\section{Parameter Estimation}

RESULT

Parameter estimation using $\mathrm{F}$ test and t test. Through data processing, we have the Log-Lin model,

LnFDI $=-20,429+2,677 \mathrm{R}+0,520 \mathrm{GRWT}+0,004 \mathrm{INF}+\mathrm{e}$ 
TABEL 6 SUMMARY OF THE REGRESSION

\begin{tabular}{|c|c|c|}
\hline & $\begin{array}{c}\text { Regression } \\
\text { Weight }\end{array}$ & Standard Error \\
\hline Constant & $-20,429$ & 8,052 \\
\hline $\mathrm{R}$ & 2,677 & 0,873 \\
\hline GRWT & 0,520 & 0,099 \\
\hline INF & 0,004 & 0,032 \\
\hline $\mathrm{N}: 132$ & \multicolumn{2}{|c|}{ Adjusted $\mathrm{R}^{2}: 0.452$} \\
\hline
\end{tabular}

Source: Data processing

\section{Determination (adjusted R2)}

In Table 6 we found the adjusted R2 is 0.452 , that mean change of FDI could be describe by R, GRWT and INF about 45,2\%, The value of adjusted R2 that close to zero (0) means the independent variable (R, GRWT, and INF) had not good enough to predict the dependent variable (FDI). If we see the value of constant -20,429, it mean if there is no existence of $R$, GRWT, and INF than FDI will decrease about 20,429\%.

\section{Hyphotheses Testing (F test)}

F test used to examine whether the independent variables (R, GRWT, INF) have jointly affect the dependent variable.

\section{Hyphtheses:}

H0: $\beta 1=\beta 2=\beta 3=\beta 4=\beta 5=0$ : The independent variables (R, GRWT, and INF) have not jointly affect the dependent variable (FDI).

Ha: $\beta 1 \neq \beta 2 \neq \beta 3 \neq \beta 4 \neq \beta 5 \neq 0$ : The independent variables ( $R$, GRWT, and INF) have jointly affect the dependent variable (FDI).

If value of $\mathrm{F}>\mathrm{F}$ table, than rejected $\mathrm{H} 0$.

If value of $\mathrm{F}<\mathrm{F}$ table, than accepted $\mathrm{H} 0$.

TABEL 7 SUMMARY OF F TEST

\begin{tabular}{|c|c|c|}
\hline The value of $\mathbf{F}$ & F Table $(\boldsymbol{\alpha}=\mathbf{0 , 0 5})$ & Decision \\
\hline 22,617 & 2,680 & Rejected $\mathrm{H}_{0}$ \\
\hline
\end{tabular}

Source: Data processing

Table 7 show that the value of $\mathrm{F}>\mathrm{F}$ table, than we should rejected $\mathrm{H} 0$. So we could said that the independent variables (R, GRWT, and INF) have jointly affect the dependent variable. (FDI).

\section{T test}

$\mathrm{T}$ test was used to detect how well the independent variables can explain the dependent variable or independent variables determine whether or not a significant effect on the dependent variable individually.

Hipotesis:

Ho: $\beta \mathrm{i}=0$ : independent variables have no significant effect on the dependent variable individually.

Ha: $\beta \mathrm{i} \neq 0$ : independent variables have significant effect on the dependent variable individually.

If t-test (sig) $<0,05$, than rejected $\mathrm{H} 0$ 
If t-test (sig > 0, 05, than accepted H0.

If value of $\mathrm{t}>\mathrm{t}$ table than rejected $\mathrm{H} 0$.

If value of $\mathrm{t}<\mathrm{t}$ table than accepted $\mathrm{H} 0$.

TABEL 8 SUMMARY OF T TEST

\begin{tabular}{|c|c|c|c|c|}
\hline Variable & $\begin{array}{c}\text { t-test } \\
\text { (sig) }\end{array}$ & Value t & t table $(\boldsymbol{\alpha}=\mathbf{0 , 0 5})$ & Decision \\
\hline R & 0,003 & $-3,068$ & 1,984 & Rejected $\mathrm{H}_{0}$ \\
\hline GRWT & 0,001 & 5,269 & 1,984 & Rejected $\mathrm{H}_{0}$ \\
\hline INF & 0,910 & $-0,113$ & 1,984 & Accepted $\mathrm{H}_{0}$ \\
\hline
\end{tabular}

Source: Data processing

As seen on table 8, we found R and GRWT have significant effect on FDI individually, but INF not

From the $t$ test we found that $\mathrm{R}$ (foreign exchange rate) has significant probability 0,003 less than 0,05 at $\alpha=5 \%$, it means that foreign exchange rate is a good predictor for FDI. And the regression weight is 2,677 , we could said if IDR decrease $1 \%$ to USD than FDI will increase about $2,677 \%$ and contrary. So the hyphotheses that said foreign exchange rate (IDR to USD) have effect to FDI in Indonesia could be accepted. Investor will considering foreign exchange rate in making invesment decision in Indonesia.

GRWT (economic growth) has significant probability 0,001 less than 0,05 at $\alpha=5 \%$, it could be said that economic growth is a good predictor for FDI and the regression weight is 0,520 . Regarding to this finding we could said if economic growth increase for about 1\% than FDI will increase for about $0,52 \%$. So the hyphotheses that said economic growth have effect to FDI in Indonesia could be accepted. Economic growth is always positive during the study period, it's indicates that Indonesia is conducive to investment.

INF (inflation) has significant probability 0,910 greater than 0,05 at $\alpha=5 \%$, its show to us that inflation rate is not good predictor for FDI, and regression weight is 0,004 regarding to this result we could said that inflation rate in Indonesia have no effect on FDI. Therefore investor not considering inflation rate into their invesment decision.

\section{CONCLUSION}

Regarding to this research we found that foreign exchange rate (IDR to USD), economic growth, and inflation rate have simultanously effect on foreign direct invesment in Indonesia, while in individualy testing found that only inflation rate has no effect on foreign direct invesment. So, we could said that foreign investors in Indonesia more considering the foreign exchange rate (IDR to USD) and economic growth than inflation rate in their invesment decision.

\section{ACKNOWLEDGEMENT}

The authors are grateful to the comments of the editor and the anonymous referees on our paper. This work has benefited from the assistance of Sudarmadi in conducting the empirical study reported here. 


\section{Reference}

Badan Koordinasi Penanaman Modal, 2006, Perkembangan Penanaman Modal, Jakarta, BKPM, Jakarta

Badan Koordinasi Penanaman Modal, 2006, Undang-Undang N0.1 Tahun 1967 Tentang Penanaman Modal Asing, BKPM, Jakarta

Ball, D.A., Wendell H McCulloch, J., Frantz, P.L., 2002, International Business: The Challenge of Global Competition (8th), the McGraw Hill Companies Inc., and New York, USA

Bank Indonesia, 2003, Buletin Ekonomi Moneter dan Perbankan, Bank Indonesia, Jakarta.

Bank Indonesia, 2013, Statistik Ekonomi dan Keuangan Indonesia, Bank Indonesia, and Jakarta.

Benassy, Quere, A., Fontagne, L., Lahreche Revil, A, 2001, Exchange rate Strategies in the Competition for Attracting Foreign Direct Investment. Journal of the Japanese and International Economies, 15, University of Paris X Nanterre, Paris, Perancis.

Dornbusch, Rudriger and Fisher, Stanley, 1995. Macroeconomics (6thed), International Edition, McGraw-Hill. Inc Gujarati, Damodar, 2003, Basics Econometrics (4thed), the McGraw Hill, USA.

Gwartney, Stroup, Sobel, Macpheuson, 2006, Economics (11thed), Thomson South-Western, USA.

Khalwaty, Tajul, 2000, Inflasi dan Solusinya, PT Gramedia Pustaka Utama, Jakarta.

Robin, Bade, Michael Parkin, 2002, Fundations of Macroeconomics, the Addison Wesley, Boston, USA.

Salvatore, D., 1997. Ekonomi Internasional. Edisi kelima, Penerbit Erlangga, Jakarta.

Sambodo, M. Arif (2003) Analisis Faktor - Faktor yang Mempengaruhi Penanaman Modal Asing di Indonesia, Tesis, Program Pasca Sarjana Universitas Diponegoro, Semarang.

Sarwedi, 2002, Investasi Asing di Indonesia dan Faktor yang Mempengaruhinya, Jurnal Akuntansi dan Keuangan. Direktur Pusat Pengkajian Ekonomi dan Sosial (PPES) Jember.

Sudarmadi, 2013, Analisis Pengaruh Suku Bunga Domestik, Suku Bunga Asing, Nilai Tukar Rupiah, Pertumbuhan Ekonomi Dan Inflasi Terhadap Penanaman Modal Asing Langsung (Foreign Direct Investment) Di Indonesia Periode 2002-2012, Tesis, Pascasarjana Universitas Gunadarma, Jakarta

Suharto, 1997, Foreign Direct Investment di Indonesia Suatu Analisa Determinan Ekonomi Mikro, Jurnal Ekonomi dan Pembangunan, FEUII, Yogyakarta.

Suparmoko, M, 1998, Ekonomi Sumberdaya Alam dan Lingkungan, BPFE UGM, Yogyakarta.

Tambunan, Tulus, 2005, Implikasi dari Globalisasi/Perdagangan Bebas Dunia Terhadap Ekonomi Nasional1, Kadin Indonesia, Jakarta.

Todaro, M. P,. 2000, Economic Development. (7th edition), Longman, New York. 